


\section{LEUCOCHLORIS ALBICOLLIS.}

\section{White-throat.}

Trochilus albicollis, Vieill. 2nde Edit. du Nouv. Dict. d'Hist. Nat., tom. xxiii. p. 426.-Ib. Ency. Méth. Orn., part ii. p. 558.-Temm. Pl. Col. 203. fig. 2.-Jard. Nat. Lib. Humming Birds, vol. ii. p. 93.

Ornismya albicollis, Less. Man. d'Orn., tom. ii. p. 78.-Ib. Hist. Nat. des Ois. Mou., pp. xxxiii et 184. pl. 63.

Lampornis albicollis, Less. Traité d'Orn., p. 282.

Basilinna albicollis, Less. Ind. Gen. et Syn. des Ois. du Genre Trochilus, p. xxv.

Colibri albogularis, Spix, Av. Sp. Nov. Bras., tom. i. p. 81. tab. Ixxxii. fig. 1.

Polytmus albicollis, Gray and Mitch. Gen. of Birds, vol. i. p. 108, Polytmus, sp. 43.

Thaumatias albicollis, Bonap. Consp. Gen. Av., p. 78, Thaumatias, sp. 7.

Thaumantias albicollis, Bonap. Rev. et Mag. de Zool. 1854, p. 255.

Leucochloris albicollis, Reichenb. Aufz. der Colibris, p. 10.

THE southern part of Brazil alone, so far as we yet know, is the native country of this very pretty and wellmarked species, and numerous are the specimens that from time to time are sent to Europe from that great emporium of bird skins, Rio de Janeiro. In some notes kindly transmitted to me by Mr. Reeves, that gentleman states that it inhabits the Provinces of Rio de Janeiro, Santa Catharina and Bahia ; that it may be seen in the neighbourhood of Rio from May until November, but never very near the city, and that at the same period it is equally abundant at Novo Friburgo.

The markings of this species are so distinct and so different from those of every other Humming Bird, that it is impossible to confound it with either of them. The sexes closely resemble each other in their markings and in the colouring of their plumage, and the young at an early age assume the adult livery.

The nest, which is of a rather large cup-shaped form, is a very beautiful structure, inwardly composed of thistle-down, and outwardly of moss thickly interwoven with strong cobwebs, over which it is coated with flat pieces of reddish-orange and buffy-white lichens, with occasionally the additional decoration of soft downy feathers. It is generally placed in the forked branch of a shrub. The eggs, as usual, are two in number, oblong in form and of a snowy whiteness.

Mr. Reeves states that the local name of the bird is Papa branca, and that it utters two different cries: one on the wing, which resembles Jack, Jack, Jack; and another when at rest, like Klaw, klaw, j̈p, j̈p.

Head, all the upper surface, wing-coverts, chin and sides of the neck, abdomen and flanks deep shining grass-green ; on the centre of the throat and breast a large patch of white; lower part of the abdomen and under tail-coverts white; wings purplish brown; two middle tail-feathers deep shining grass-green, the remainder bluish black, the three outer ones tipped with white; upper mandible black; basal two-thirds of the lower mandible fleshy, apical third brown; feet brown.

The figures are of the natural size. 


\section{$2 \mathrm{BHL}$ Biodiversity Heritage Library}

Gould, John. 1860. "Leucochloris albicollis, White-throat. [PI. 291]." A monograph of the Trochilidae, or family of humming-birds 5, https://doi.org/10.5962/p.317100.

View This Item Online: https://www.biodiversitylibrary.org/item/108806

DOI: https://doi.org/10.5962/p.317100

Permalink: https://www.biodiversitylibrary.org/partpdf/317100

\section{Holding Institution}

Smithsonian Libraries

\section{Sponsored by}

Smithsonian Institution Libraries

\section{Copyright \& Reuse}

Copyright Status: NOT_IN_COPYRIGHT

This document was created from content at the Biodiversity Heritage Library, the world's largest open access digital library for biodiversity literature and archives. Visit BHL at https://www.biodiversitylibrary.org. 